\title{
The Contribution of the International Organization of Francophonie in Cultural Matter in the Republic of Congo from 1981 to 2016
}

DOI: https://doi.org/10.47175/rissj.v2i4.315

\section{| Hortense Kouya Kouya ${ }^{1}$ | Dominique Oba² |}

${ }^{1}$ Marien Ngouabi University, Faculty of Letters, Arts and Human Sciences, Brazzaville, Republic of Congo

${ }^{2}$ Marien Ngouabi University, Teacher Training College, Brazzaville, Republic of Congo

${ }^{1}$ nzoussi@yahoo.fr

²dom.oba2013@yahoo.fr

\begin{abstract}
Colonization has had a lasting impact on African life. This movement instilled a new culture within these colonies. Among these African countries is the Congo. On the whole, these countries have experienced some disputes near where it was a question of meeting around an international body which is none other than the Francophonie for the countries or states colonized by France. It is in this sense that under the leadership of three African Heads of State, Léopold Sédar Senghor from Senegal, Habib Bourguiba from Tunisia and Hamani Diori from Niger, and of Prince Norodom Sihanouk of Cambodia, the representatives of 21 states and governments signed in Niamey, on March 20, 1970, the convention establishing the Agency for Cultural and Technical Cooperation (ACCT). New intergovernmental organization based on the sharing of a common language, French. The Congo being colonized by France adheres to the International Organization of Francophonie on December 7 to 9, 1981, during the general conference held in Libreville, Gabon. And the Congolese government has come to understand that ensuring a better vision on culture and politics can lead the Congo to sustainable development. Hence the need for the Congolese state to cooperate with the International Organization of Francophonie for better visibility for the cultural and political promotion of the country. This is what the subject of our study is: the contribution of the OIF in cultural and political matters in the Republic of Congo from 1981 to 2016.

KEYWORDS

Contribution; OIF; made cultural; development; Republic of Congo
\end{abstract}

\section{INTRODUCTION}

The French initiative to exclude cultural property from GATT agreements was not only successful thanks to the support of the twelve member states and member governments of Francophonie gathered for their fifth summit in Mauritius in $1993^{1}$. Since then, it has been an important element in the action of the International Organization of Francophonie.

The expression cultural diversity will then take precedence over that of cultural expression considered too defensive and will be at the heart of the third ministerial conference on culture in Cotonou on 14 and 15 June 2001: fifty-five member states and governments or observers of Francophonie came together to renew their cooperation and organize the defense of cultural diversity in the face of new developments in globalization by adopting an action plan for the current decade ${ }^{2}$. Member States have also determined

\footnotetext{
${ }^{1}$ Fifth Francophonie Summit, Grand-Baie (Mauritius), October 16 and 18, 1993

2 This action plan is based on the commitment made by the Member States to study the establishment and strengthening of frameworks favorable to cultural diversity, in particular in the following areas : language policies, promotion of cultural diversity in education systems, development of the diversity of audiovisual
} 
their position for the WTO meeting in December 2001 was Qatar, confirming the desire of Francophone countries to participate in the development of a binding international legal instrument to promote cultural diversity, as well as their refusal to make commitments to release cultural goods and services ${ }^{3}$.

The official theme of the ninth summit in Beirut, the dialogue of cultures will also be an opportunity for French-speaking heads of state and government to assert a critical position on the international scene ${ }^{4}$ by estimating "We confirm our desire not to allow cultural goods and services to be reduced to the rank of simple, commodities ${ }^{5}$. We reaffirm the right of our states and governments to freely define their cultural policy and the instruments which contribute to it. We are determined to bring these positions to fruition in the various international forums". And the French-speaking leaders estimate that under the conditions of estimating that under the current conditions, the presentation of cultural diversity implies to refrain from any commitment of release to the WTO in matters of cultural goods and services, and this, so as not to compromise the effectiveness of instruments aimed at promoting and supporting cultural diversity. In addition, the French-speaking Heads of State and Government declared themselves, " determined to actively contribute to the adoption by UNESCO of an international convention on cultural diversity, enshrining the right of States and governments to maintain, establish and develop policies to support culture and cultural diversity" 6 .

Throughout 2003 and 2004, Francophonie continued its supportive action so that a normative convention, guaranteeing the capacity of States to develop and implement cultural development policies, is adopted and can enter into in force before the current round of WTO negotiations is completed. The recommended constitution of "a working group responsible for contributing to the international debate, in particular at UNESCO and in other forums such as the International Network for Cultural Policy (INCP) "has already been implemented by the Secretary General, Abdou Diouf, who installed this group on January $17,2003^{7}$. Respect for the status of French in international organizations is also part of this dynamic.

Cultural diversity thus has a double dimension: in the protection of national or subnational cultures and in opening up to other cultures in a context of non-discrimination. With a constant, the differentiation of cultural goods compared to other economic goods. The promotion of linguistic and cultural diversity aims to prevent the risk of drift that can

media and cultural offer, strengthening of regulatory bodies, supports the creation and development of cultural businesses, etc.

${ }^{3}$ We believe that, under current conditions, the way to preserve cultural diversity remains to refrain from making liberalization commitments in the area of cultural goods and services, in particular within the framework of the negotiations of international agreements, such as at the WTO : third ministerial conference on culture of the International Organization of La Francophonie, Cotonou, 14-15 June 2001.

4 "By culture, we must understand the entire range of acquired modes of human behavior and, considered under their symbolic aspects, all the past and present works of human societies ..., by co- forming process of the symbolic systems specific to each cultures; reflection document around the Theme of the Summit "the dialogue of cultures, ninth of the Francophonie, Beirut, October 2002.

${ }^{5}$ Already in 1993, President Mitterrand declared: creations of the mind are not commodities; services of culture are not simple businesses. What is at stake is the identity of our nations, and identities cannot be negotiated"

${ }^{6}$ On 2 November 2001 the 31 General Conference of UNESCO adopted a Universal Declaration on Cultural Diversity, called the «founding document" by its Director General Keiichiro Maqsura .. For that cultural diversity is ensured in accordance with Declarations of a number of requirements will have to be fulfilled, such as the right of everyone to exercise and express their own cultural practices. On October 7, 2003, UNESCO adopted a new recommendation on the use of multilingualism and universal access to cyberspace.

${ }^{7} \mathrm{Mr}$. Abdou Diouf, former President of Senegal (1981-2000), was elected to the post of Secretary General of La Francophonie, replacing Boutros Boutros Ghali, for a four-year term, renewable at the end of the Beirut Summit. He officially took office on January $2,2003$. 
generate globalization the objective is to prevent it from becoming a source aggravation of inequalities and negation of identity and that it is, on the contrary, a factor of development. Francophonie was a real laboratory of cultural diversity which is linked to democratization, sustainable development, peace, fundamental freedoms and human rights.

Law No. 25-95 of November 1995 amending the School Act No 008/90 of 1990 and 6sept.-bearing Change event of the education system in Republic of Congo, in Article 1. Any person has the right to education. The teaching public is free. Basic education is compulsory. This is to say that education is a vital sector whose results have direct effects on the development of the Congo. This article which has for starting field, 1981 is justified by the adhesion of Congo to the OIF and 2016, the date of the presidential election of 2016. This article thus proposes to study you with the contribution of the International Organization of Francophonie in Cultural Matters in the Republic of Congo from 1981 to 2016

\section{RESULTS AND DISCUSSION}

\section{The contribution of the international organization of Francophonie to cultural promotion in the Congo from 1981-2016}

All organizations have been confronted from their origins with the need to come together while regulating conflicts, among these, the organization of society and the exercise of power have been resolved in different ways over the ages ${ }^{8}$.

The relations of cooperation between the Congo and the former metropolis, and consequently with the organizations which were close to it, were qualified as neocolonialist, even if, as Mapana Matsouma acknowledged by saying the following:

The defection of relations of cooperation with capitalism did not bring about the challenges of development, necessarily cultural, advocated by the socialist system and the authorities of the time ${ }^{9}$.

According to Louis Sabourin et al:

The Francophonie appears as a physical and conceptual whole, which is forged around a desire, a will to think and act together ${ }^{10}$.

Fully aware of these issues, the International Organization of Francophonie has since been committed to cultural promotion by supporting the development of cultural industries in its member states. Its cooperation policy aims not only to promote influence and dialogue with the cultures of the southern countries of the French-speaking area, but also to support States to strengthen their economic potential, so that the undeniable potential of the sector culture in terms of wealth creation, jobs and social cohesion can continue the development of these countries.

The intermediate poverty reduction strategy (I-PRSP) in 2004 and the achievement of the decision point of the HIPC initiative in 2006; the Congolese government adopted a poverty reduction strategy document (PRSP) final in 2008. This revolves around a few useful points such as:

\footnotetext{
${ }^{8}$ N Tenzer, 1991, Politics, What do I know ?, Paris, PUF, p.25

${ }^{9}$ Mapana Matsouma Thomas, 1993 The Agency for Cultural and Technical Cooperation of the Francophonie and cooperation with the Congo, Diploma thesis from ENAM , Brazzaville, p. 80

${ }^{10}$ Louis Sabourin, Gérard Conac , and Christine Dessouche Christine , 1987, The French-speaking multilateral cooperation Paris, Economica , p. 26
} 
1. Improving governance and consolidating peace and security;

2. Promote growth and macroeconomic stability;

3. Ensure the improvement of the populations' access to basic social services;

4. Social environment and integration of vulnerable groups;

Culture was finally added as a priority in the final version adopted in 2008 . The stated objective is to "promote culture and the arts as a link in sustainable development". As a result, three orientations have emerged, including:

1. Strengthening of the institutional framework in the fields of culture and the arts;

2. Promotion of culture and protection of cultural heritage;

3. Promotion of the arts.

Make the cultural sector one of the levers of economic growth. Indeed in CongoBrazzaville the objective of the International Organization of Francophonie is to proceed with the national institutions of this country, to an inventory of the cultural sector in order to contribute to the constitution of a lasting tool of information for public authorities and professionals. This is why the information available to the public authorities on the realities and needs of the cultural sector is essential to provide appropriate support to the sectors. However, in many countries this information is often lacking. At the very least, it remains incomplete due to the lack of dedicated systems, financial and human resources available to the public authorities, but also due to the shifting and often informal nature of this emerging economic sector.

In 2011, as the technical operator of the OIF, the Culture and Development association coordinated this work in Congo, with the invaluable support of the authorities of this country, cultural professionals and Congolese consultants thanks to the work investigators deployed in the field, including 218 in Congo and 288 in Gabon. In these three countries, the project has made it possible to highlight cultural sectors under construction, led by dynamic cultural operators despite a market whose development remains limited.

Very diverse artistic landscapes, between tradition and innovation.

First, the field surveys revealed the great diversity and dynamism of cultural expressions that characterize each of the countries covered. Indeed, the Congo is rich in a mosaic of cultures with a multiplicity of languages of know-how and cultural expressions in fields as varied as audiovisual, literature, music, dance or sculpture. For example, Congolese rumba originally influenced by Cuban music, itself based on African rhythms imported into the Caribbean by former slaves. Born in the 1950s, on the two banks of the Congo River between Brazzaville and Kinshasa, the rhythms of the rumba made the fame of the Congolese music by spreading on all the continent and even in the diasporas.

The historic influence of Brazzaville as a major pole of African music of the 1960s is today extended by the Organization of the Pan-African Music Festival (FESPAM) which, every two years, brings together musicians from all over the continent. If music appears as a particularly important creative breeding ground in each of the countries, the other fields of artistic creation are also experiencing an undeniable vitality, whether one thinks for example of the quality of Congolese literature or the dynamism of Gabonese filmmakers and videographers. Cameroon.

It emerges that both Congo and Gabon have varied and dynamic artistic scenes. This is a major potential to be exploited for the development of the Congo, given the unifying effect of these cultural expressions, but also the significant economic benefits that may result. Due to the weight of the informal sector and the mistrust of certain operators. In Congo, the total number of jobs has been estimated at least 2,625 and the cumulative turnover at least 831 million XAF, more than 4 billion XAF if the FESPAM budget is included. 
Although it is necessary to consider these figures resulting from the declarations of the operators and certainly underestimated, they give an order of magnitude of the direct contribution of the cultural sector to the development of the country. Thus, the Congolese music industry generates a turnover of at least 707 million XAF francs and that of publishing in Gabon generates a turnover of at least 1.3 billion CFA francs, mainly driven by the press economy, which benefits from a support fund. Backed by the communication market and developed on the Nigerian model of Nolly wood.

However, it is the cultural heritage and arts and crafts sectors, in particular the reproduction of antiques, which are the most economically active because of their importance for tourism but also thanks to the development of the sub-regional and international market. .

The OIF has also encouraged the Congo to face more, first and foremost, the challenge of developing efficient domestic markets, structured around the most active sectors such as music, audiovisual and heritage.In order to increase its share in the international trade of cultural products. The development of these sectors is destined to be integrated into strategies aimed at the development of the economy of cultural tourism services and regional planning. Indeed, the OIF to better ensure its mission it will be desirable to see all the sectors in the field of culture

Cultural issues in all sectors of what is called "culture", the Francophonie has played a leading role. It would be tedious to try to list all the forms of action that are carried out. But several areas deserve special attention.

Writing, books and literature; despite the rapid development of information and communication technologies, books continue to play an irreplaceable role in our modern societies. It constitutes a major stake as a tool for transmitting knowledge, disseminating and preserving it. Access to writing and mastery of reading are determining factors for social integration. The difficulties are great in French-speaking countries with an oral tradition, which are also poor, and where the rate of schooling and literacy has not yet reached a high level. France's action to promote French books within the framework of a budget which is progressing very little despite the contribution of private partnerships is encountering stiff competition, even if the number of translations from French has increased and exceeds six thousand $(6,000)$ per year. A plan for a joint agency between the two ministries (MAE and Culture) which are the players in book policy abroad should rationalize the current system. In this area of book promotion, several types of actions are carried out, by the International Organization for the Francophonie, but also by communities of the Christian religion, in order to promote the establishment of "reading networks", in particular libraries which UNESCO says constitute one of the main links in cultural policy. In other words, access to books guarantees access to knowledge.

French-speaking literature, which, since 1926, became aware of its vitality and its richness by creating the Association of French-speaking writers - is written on all continents: it is rich and multiple. If this French-speaking literature does not yet have a significant "market share" in terms of book sales at the global level, the reasons do not relate to the quality of the authors and their works, but rather to a "political commercial "insufficient.

This French-speaking literature has developed on the African continent and the French language is enriched there by a phrasing, a rhythm and typically African sources of inspiration, thereby translating a cultural claim: it had started, in particular, with a premonitory review, "African presence", created in 1947 by Mr. Diop. French-speaking African authors are numerous and known throughout the world: some for a long time such as, for example, Léopold Senghor (Senegal), Ahmadou Kourouma (Ivory Coast), David Diop (Senegal ), Alain Mambanckou (Congo Brazza, prize Renaudot for Memories 
de porc -épic published in 2006), D. Biyaoula , Jean-Roger Essomba, and others who have appeared a few years ago, born only like Fatou Diome (Senegal) for whom "French is not seen as an endured language. , but like a desired language, loved, savored,... ", Marie Ndiaye. French-speaking writer of Senegalese origin, who has lived in Berlin since 2007, published her first novel at the age of 17. She obtained the Femina Prize in 2001 and published, in 2009, a novel: Three strong women. She says, "I like the idea that a book is readable on many levels by all kinds of very different people." The creation of Literature Prizes, such as the Five Continents Prize or that of the Young Francophone Writer is a recognized means of promotion, such as the presence, for the first time, of an African book pavilion at the 18th Geneva Book Fair in May 2004.

The African continent has many other talented writers. Without wishing to mention them all, we can name a few: Hamidu Kane (Senegal), Boubacar Diop (Congo), Emmanuel Dongala (DRC), Wilfried N'Sonde (Congo), a former musician who successfully turns to music. Writing (prize of the 5 continents of the Francophonie), Henri Lopes (Rwanda), Mme Scholastique Mukanga (Rwanda), Nimrod (Chad). Some of these writers came to live in France, Europe or the USA. For Alain Mabanckou, professor of literature at the University of California-Los Angeles, it is a rich, diverse and deterritorialized literature.

It would be interesting, given the cultural importance and the fame that these writers (and so many others who are not mentioned here) have, to see what place is reserved for them in the textbooks of French literature in the colleges and high school in France and, in the event that this place is not the one that should be theirs, to know the real reasons, starting with the content of the teacher training system and the choice of programs in secondary education. At a time when practically all secondary school students have daily access to the Internet and travel to the four corners of the world, it is paradoxical to note that the official literature programs only exceptionally mention the works of Francophone writers other than French. . In this area, the great linguist Claude Hagege is right to say that the defense of the French language is a struggle and that we must consolidate the start that we can currently detect.

Image and sound; our current world is characterized by the increasing importance of images and airwaves: everywhere we listen to the radio and very often we watch television. In addition, the cinema still has an important place. The Francophonie must therefore be present in this area.

In terms of television: two French-speaking television channels exist:

a. TV5 Monde is a general-interest television channel that speaks French: installed on around twenty satellites, bouquets and 6,000 cable networks, it reaches around 400 million people (nearly 200 million households), in nearly 200 countries. It is ranked 3rd among the largest global chains in terms of networks. It is the result of cooperation between Belgian, Swiss, Quebec, Canadian and French channels (France television, la Sept-Arte, RFO, INA). It launched TV5 Africa and TV5 Asia.

b. France 24: it is a French international news television channel. It was launched in 2006. It broadcasts in French, English and Arabic, 24 hours a day, 7 days a week. Its news bulletins are broadcast every 20 minutes. Each day of the week, a program is devoted to a continent (Americas, Asia, Middle East, Europe, Africa, Maghreb and France). For radio, the place that Radio France International (RFI) has taken is important. It is the 3rd international radio station with 44 million listeners (behind BBC World and Voice of America). It broadcasts in French, but also in 189 foreign languages; it has a well-researched program bank, which is 
used, in part, by the fifty or so local radio stations which, historically, had been created or supported by the AIF.

Today, RFI has subsidiaries: Monte Carlo Doualiya which broadcasts in the Middle East and the Maghreb; Radio Europa Lisboa which broadcasts in French and Portuguese; RFI Sofia in Bulgaria; Radio Delta RFI FM in Bucharest for Romania and RFI- Deutschland. Francophone radios also include:

a. RTBF International, which is the international radio station of the Belgian radiotelevision of the French Community; it broadcasts in Belgium, but also in Kinshasa (in FM) and it is accessible in Europe and Africa by satellites;

b. Africa 1. It is the first international generalist radio station on the African continent. It is located in Gabon. It has 31 million listeners, mainly in Africa, but also a little in France and North America. She is considered "the Voice of Africa";

Radio Méditerranée Internationale (Medi ). It is a private generalist radio station which broadcasts in French and Arabic which covers the Mediterranean basin with approximately 23 million listeners. News agencies.

One of the main press agencies in the world is French ${ }^{11}$. French is his main working language. The Pan-African News Agency, created in 1963, at the same time as the Organization of African Unity - OAU) has the largest network of correspondents on the continent. French is, along with English, Arabic and Portuguese, the working language. The Syfia Agency is the first private association agency specializing in Southern countries and Africa. It was created in 1988 and brings together 10 press agencies (Belgium, Benin, Burkina Faso, Cameroon, Canada, France, Madagascar, DR Congo, Senegal and Switzerland). Its network supplies around 200 French-language titles in Asia, Africa, Europe and Canada.

Other tools exist: MCM international, which is a musical television channel, present in some thirty countries on all continents, but also French-speaking educational channel, which is a digital educational radio station, etc. All these tools benefit from financial support, the objective of which is to help productions, encourage the quality of products, the transfer of skills and the expansion of audiences.

Francophone cinema is present at major events such as the Cannes Film Festival, the Paris Film Festival, the Namur Film Festival, the Canada-Quebec Film Festival, Carthage, Cairo, Marrakech, Burkina Faso and many others. Occasions in all French-speaking countries: African cinema, cinema from the Maghreb and the Middle East, Belgian cinema, that, in full development, from Quebec, are alive, imaginative and they travel. We should also note the case of Mr. Rithy Panh , filmmaker survivor of the Khmer Rouge camps in Cambodia who says: "French saved my life". But often, the lack of means and structures constitute difficulties which hamper production and especially distribution.

French-speaking music, (we could, moreover, speak of French-speaking music!), For its part, is very much alive, (like other music as well): the number of festivals that have been devoted to it for a long time (Les Francofolies de La Rochelle, or the Limousin festival, that of Abidjan, Ouagadougou, the Midem of Cannes, etc.) and the events where it is present as such (as in Quebec for example), are there to demonstrate all its influence and, beyond that, the richness of cultural diversity in this area.

A particular light can be brought to the Cajun music. This has been in full revival since the 1960s / 1970s and a radio station has specialized in it. Every summer, Finally, it is worth

\footnotetext{
${ }^{11}$ Agence France -presse, AFP, created in 1835.
} 
remembering that historically the French people who populated Louisiana gathered on Sunday afternoons to "chat", that is to say to talk, sing, dance. The encounter with the music and songs of black slaves gave jazz.

Sport and games; Without mentioning all that sport can bring on a personal and collective level in terms of a balancing factor, solidarity, social promotion, but also by not concealing the excesses of certain sports practices, it must be recognized that sport has a place very large in our societies. The Francophonie is no exception to this phenomenon, but it has approached it in a particular way. In this area, it has a tool, the Conference of Ministers of Youth and Sports of countries sharing french in common (CONFEJES) which, in particular, organizes the Games of La Francophonie ${ }^{12}$.

These Games take place every 4 years (like the Olympic Games). The first edition took place in 1989 - the bicentenary of the French Revolution - in Morocco (Rabat and Casablanca); then the Games of La Francophonie were held in Paris (1994), then in Antananarivo (1997), then in Ottawa (2001), in Niamey (Niger, 2005); then Beirut (Lebanon 2009). The next games are to be held in Nice, in 2013. These Games revive the very essence of the Games of Antiquity, which brought people together and brought together "the exercise of the body and the mind": alongside the exploits of the athletes, there is the creativity of artists. This is the reason why the Games of La Francophonie bring together six sporting events: athletics ( Men / Women ), basketball ( Women ), football ( Men ), judo ( Men / Women ), boxing (Men ) and table tennis (Mike / Women) and seven "trials" culture: songs, stories and storytellers, dance creation and traditional inspiration, literature (short story), painting, photography and sculpture.

In addition, an animation event was presented: the traditional wrestling which, in a country like Niger, brings about the synthesis of sport and culture. Both by their concept, unmatched to date, and by the number of participants (around 3,000), the Games of La Francophonie constitute an international sporting event (recognized by international sports federations) and a place of expression of diversity culture and talents. Many other aspects of what is called "cultural life" could be evoked, showing that the Francophonie lives in these disciplines thanks to a web of solidarity relationships that have been created: this is the case, as a simple example, fashion where African creativity has a growing place.

The influence of a language (and through it, a way of life and a conception of relations between peoples) in a world where "events" (cultural, sporting, etc.) are immediately known and seen from the outside a growing number of people cannot be reduced to the control of these means or to this type of manifestation: but it would be suicidal for them to ignore them. The image seduces and impresses; writing and speaking call for reflection. Image, writing and speaking are complementary.

\section{Cultural Diversity}

On October 21, 2005, the General Assembly of UNESCO, on the occasion of its 33rd General Conference, adopted the draft Convention on Cultural Diversity. This Convention:

- recognizes in international law the specific nature of cultural goods and services as carriers of values, identity and meaning;

- affirms the right of States to adopt cultural policies aimed at ensuring a genuine diversity of cultural expressions by resorting to means of intervention sometimes in contradiction with international free trade standards;

- establishes provisions by which rich countries undertake to help developing countries support the promotion of their own emerging cultural industries;

\footnotetext{
${ }^{12}$ Francophonie passport website www. Francophonie.Org
} 
- establishes the principle of non-subordination which will give the Convention a status in international law equal to that of any international treaty.

Finally, it is interesting to note that this vote was made possible thanks to the support of the Organization of Ibero-American States, the Community of Portuguese Speaking Countries and the countries of the Latin Union, which supported the proposals and positions. Of the OIF, which, from a geopolitical point of view, should be emphasized.

However, the Unesco vote ${ }^{13}$. no rule, of course, not all. But this Convention entered into force on March 18, 2007 since the number of ratifications received by the Director-General of UNESCO amounted, on that date, to nearly 50, which was already sufficient for its implementation, a number to which s 'adds, and this is very interesting, the European Community. This Convention is the third voted by UNESCO in cultural matters after that of 1972 on world heritage and that of 2003 on intangible heritage.

Several questions now arise. The first is that of ratification by the States which had declared themselves in favor of the vote during the General Assembly of UNESCO. Each State has; of course, its own ratification procedures and the texts in force must be respected. But it seems obvious that the more the number of States which will have ratified it, the more its implementation will be facilitated. Indeed, and this is the second question, the fierce opposition of the United States to this text is not over and the American government is increasing the number of bilateral agreements including cultural goods (which constitute the second item overall. of their exports) among others, which will prevent the Contracting States from ratifying a convention which would then be contrary to the bilateral agreement. The Convention does not call into question international economic law, but it specifies that it is not subordinate to it.

As Claude Hagège says ${ }^{14}$ "the promotion of the linguistic diversity of the world is linked to that of French". Support for cultural diversity (and therefore for the diversity of languages) is a factor in the strengthening and development of identities and languages and their constant respect in all fields.

A concrete example of respect for cultural diversity deserves to be highlighted. The company Sanofi Aventis, which results from the merger of a French company (Sanofi) and a German company (Hoechst), implemented simultaneous translation during meetings of its Executive Committee, each member s 'expressing in his own language, without any reference to English. Likewise, the internal newspapers contain only articles in German and French. There are lessons to be learned here.

The citizens of the member states of the Francophonie practice recognized religions of great diversity. The monotheistic religions are the most important, but Buddhism, animism and the "non-religious" are present. Among the monotheistic religions, the Catholic religion, the Protestant religions, the Orthodox religion, the Jewish religion and the Muslim religion are very established, even if the number of practitioners of each of them can vary.

In the religious domain, French has an important place: it remains the diplomatic language of the Vatican, the one the Pope uses when he receives foreign ambassadors, the one that the current Pope, Benedict XVI, used during his trip to Turkey. For example. In international meetings in the Vatican, there are three language groups: French, English and Spanish.

All French-speaking states do not yet know the principle of state neutrality vis-à-vis religions, in other words, secularism, which is not an attitude against religions, but the affirmation of the right of everyone to believe or not to believe and to freely practice one's

13148 votes in favor of the text proposed in particular by the French-speaking countries which were its precursors in 1999 at the summit of heads of state in Moncton

${ }^{14}$ Cf newspaper " Le Monde " of March 9, 2010 
religion. The most current question, and perhaps the most worrying, is that of the development of religious extremism (in many states, French-speaking or not, for that matter) regardless of the religion concerned.

The legal diversity, or, more precisely, the diversity of legal systems within Frenchspeaking countries, is great and covers practically all the legal systems existing in the world.

These systems can be distinguished as follows:

- In the world there are two major legal systems: the system of law of civil law or Romano-Germanic tradition (nearly $60 \%$ of the world population is directly or indirectly influenced by this system) and the system of Common Law (35\% of the population is affected).

- For the rest there is Muslim Law (whose basis is the Koran), Talmudic Law (in force only in Israel) and Customary Law (few countries are entirely influenced by it; but it can be integrated with another system).

- In the system of civil law tradition, largely inspired by the Roman heritage, the law is, above all, written: the rules of law are codified. In the common law system, the expression of law is mainly given to case law and not to law. Within the member countries of the Francophonie, the majority of the legal systems in place are of written law alone, (ex: Belgium, Benin, Cambodia, Cape Verde, France, Haiti, Romania, Vietnam, and); in other cases, written law is supplemented with customary law or Muslim law (Burkina Faso, Congo, Côte d'Ivoire, Gabon, Madagascar, Mali, Senegal, Chad, Togo, etc.), for customary law and, for its association with Muslim law, the Comoros, Egypt, Lebanon, Morocco, Tunisia, Mauritania, etc. The Common Law system, alone, is found in Canada (outside Quebec), Dominica, and New Brunswick. The customary law system alone is found only in Andorra; associated with other systems, it is found, apart from the cases already mentioned, in Vanuatu where the legal system is a mixture of Civil Law, Common Law and Customary Law.

Thus, the Francophonie brings together countries where the traditions of living together are expressed in profoundly different legal systems. This legal diversity which concerns the substance of the Law, but also the organization of the role of the actors of the application of the Law, of the control and of the sanction in the event of breaches, is a wealth because it allows establishing interesting comparisons and enriching ${ }^{15}$.

The conviction that wealth comes from diversity is at the heart of Francophonie's commitment to cultural and linguistic diversity. Its role in the adoption by UNESCO of the Convention on the Protection and Promotion of the Diversity of Cultural Expressions has earned it international recognition.

The OIF implements support programs for French-speaking writers, filmmakers, musicians, visual artists and digital art creators, allowing better dissemination of their works around the world and access to international audiences and markets. The cultural policies of French-speaking countries and the cultural industries sectors are supported in particular to exploit the opportunities offered by digital technology. Reading for all as an essential vector of knowledge is favored by the OIF through its flagship program of reading and cultural activities centers located in rural and peri-urban areas ${ }^{16}$.

The cultural cooperation policy here refers to all the orientations which guide the action of the Francophonie in the field of culture; and its implementing instruments, the bodies or

\footnotetext{
15 The challenges of the Francophonie

${ }^{16}$ www . Francophonie. o rg . 1 has Francophonie passport website
} 
institutions responsible for translating these guidelines into practice. In this regard, Professor Gonidec writes:

Cooperation is one of the modes of international relations which involves the implementation of a policy (therefore of a strategy or a tactic) pursued for a certain period of time and intended to make it more intimate thanks to mechanisms permanent, international relations in several areas without calling into question the independence of the units concerned ${ }^{17}$.

The OIF's cultural cooperation action is led by the Agency Intergovernmental de la Francophonie (AIF). It embraces all sectors of political, economic, cultural human activity, etc. Indeed, culture holds our attention as a vital element of development Léopold Sédar Senghor said during a general conference of ACCT the following:

Today, many thinkers and researchers are increasingly convinced that a vision of development that sacrifices culture to economic growth, could give only incomplete development ${ }^{\prime \prime} 18$

But, culture is an anthropological notion considered as;

"The specific kind of life of a people or a society and on the concept of development, considered as the widening of the choices that the individual can make to lead the type of life to which he values "19

From then on, we can have a notion that the Congo possesses in cultural matters, priority axes characterized by a certain number of elements. Towards which are oriented not only its own efforts, but also the contributions of partners in general and those of the Francophonie in particular.

Congolese cultural policy has experienced a major revival in recent years. The ambitions of the Head of State and Government in cultural matters were set out in the Poverty Reduction Strategy Document (PRSP) adopted in 2008, in order to promote culture and the arts as a link in sustainable development, this objective was made concrete by an in-depth reorganization of the Ministry of Culture and the Arts, and above all by the adoption of Law No. 9-2010 of July 26, 2010 on the orientation of cultural policy. Particularly ambitious, this law sets out the responsibilities and means of action that the State must implement to promote the development and democratization of cultural action, the preservation of the national cultural heritage, or the development of cultural industries. .

In line with this law, major projects have been studied, such as the construction of a Palace of Culture and a city of FESPAM, or the organization of a Biennial of Letters and 'a Contemporary Arts Forum. However, the lack of funding available to the Ministry of Culture and the Arts penalizes their realization. It is delaying the achievement of the government's ambitions to make culture a centerpiece of the country's economic and social development, while the diversification of national production is recognized as a priority.

\footnotetext{
${ }^{17}$ P . F Goniced et chavrin, 1981 , International relations, P aris, Montchrestien, p.18

${ }^{18}$ Léopold sedar Seng hor, quoted by Emile Morwoha " ACCT , 1970-1995, 25 years in the service of development and French-speaking cooperation " P aris, ACCT 1995, p.117

${ }^{19}$ World Culture Report, 2000UNESCO, Paris, p. 295
} 
The Cultural Actions of the International Organization of the Francophonie in the Congo

The activities carried out on the national territory, for a two-year program the Intergovernmental de la Francophonie (AIF) ensured the actions to be carried out throughout the French-speaking area. These actions were budgeted and programmed, these activities carried out some were carried out and others suffered a good number of obstacles which intervened.

The actions of the OIF in the field of culture do not explicitly target the mobility of professionals as such;

- The OIF has programmed: the convention on the protection and promotion of the diversity of cultural expressions, the ten-year strategic framework, the 2004-2014 strategic framework, the Single Multilateral Fund (FMU), the program criteria, the support program the circulation of live performances, support for the performing arts and performing arts markets, DAK'ART and the African Photography Meetings, Francophonie games, training in book professions by CAFED;

- In the cinema, the "image " program, the Francophone audiovisual production fund from the South (operation, eligibility criteria, results), the international promotion grant for a film from the South, OIF support to festivals and professional meetings ;

- For television, the OIF covers: support for regional co-productions in the south, the OIF promotional umbrella on international markets and finally support for technical equipment, training and professional meetings. The OIF, through the AIF to ensure several activities in favor of the culture of the Republic of Congo.

\section{The Pan-African Music Festival/ FESPAM}

The Pan-African Music Festival (FESPAM) is a major biennial cultural and scientific event which essentially aims to promote the music of the African continent and its diasporas in its triple traditional, modern and religious dimension.

History of FESPAM begins with the Estates General of Paris in 1996 and those of Rome in 1959. During these major meetings, African intellectuals unambiguously assert the concept of a festival of cultures: "the black (...) will be able, little by little. Little, to signify its presence, by contributing to the recreation of a humanism to the true measure of man", they underline.

In 1966, Dakar organized the world festival of black arts. Then, it is in Algiers that will be organized, in 1969, an event which takes into account all the cultural and artistic disciplines. The conference of culture ministers held in 1969 in Port Louis (Mauritius) refined the concept and gave it a precise outline.

Later, Lagos in turn, tried to organize this type of cultural event, without much success. The misfortune of these experiences is explained by the costly nature of the organization of a large-scale festival.

After a long sleep, the idea resurfaced. With solemnity, it took shape in 1955, at the end of a summit of the Organization of African Unity (OAU). The Republic of Congo is thus designated to host this great cultural event. This choice is experienced as a consecration for this country which conceals talents in music, literature, sculpture and painting.

\section{The Contribution of the International Organization in the Field of Education}

Education is one of the areas where solidarity is expressed and where the Francophonie is committed to promoting education policies for all, based on the values of equity, solidarity 
and tolerance ${ }^{20}$. During the world education forum held in Dakar in April 2000, with the entire international community, La Francophonie decided to achieve, by 2015, a threefold objective : access to all children to a quality primary, compulsory and free education; 50 percent improvement in adult literacy levels, especially women ${ }^{21}$; guaranteeing all adults equitable access to basic education programs. To support national efforts, a strategy has been developed by the international EFA (education for all) partners, based on a partner within the United Nations Girls' Education Initiative (UNGEI), an initiative launched in 2000 by Unicef to put questions of sexual discrimination on the agenda of all education forums, in order to obtain from the States concerned the revision of their policies and their laws still contrary to the international instruments related to gender parity in education. For its part, the Intergovernmental Agency of La Francophonie, for its 2002-2003 biennium, refocused on interventions calling more on the transfer of expertise (educational engineering) in order to support Southern States. In the design and development of education and vocational training policies ${ }^{22}$. However, the difficulties in achieving the goals set in Dakar should not be minimized: the problem of financing EFA and its management constitutes the first obstacle, especially since, even though the illiteracy rate is declining, donors are reducing their participation in programs. However, the Dakar goals are not utopian; they constitute an acceptable minimum threshold below which the term global village lost its meaning; mobilizing against illiteracy also means mobilizing for better hygiene conditions, for the fight against poverty and pandemics ${ }^{23}$, as does the French-speaking world, which thus poses itself as an actor in globalization.

Education for all, one of the main Millennium Development Goals, is an international commitment also made by the Francophonie, because access to compulsory and quality primary education is a real gateway to development and employment.

To improve the quality of basic education, the OIF is helping to strengthen the skills of teachers and education managers. Through multiple programs, it provides training for teachers, some at a distance, using new technologies (Ifadem) and others face-to-face (Initiative ÉLAN-Afrique) as well as the production of tools educational according to the different cultural and linguistic contexts of the countries of the African-speaking, Creolespeaking and Arabic-speaking areas. Learning a trade is based on the knowledge acquired at school and on professional skills. The OIF promotes dialogue between States and companies to develop vocational training programs in sectors with high employment potential.

\section{The educational demands of the Congo in the structures of the Francophonie}

Since men have experienced this in society throughout all periods, educational action has always guided their steps. Through this action they seek to lead children and adolescents by inculcating in them the general concepts of life and by transmitting to them all the necessary knowledge which they have inherited from previous eras. Through this work the men aim at a precise objective, to have pupils and students well educated to avoid the catastrophe and to make both the wealth of the country. The Congo, like any member country of the OIF, has had requests in French-speaking structures related to education and vocational and technical training and requests relating to support for educational structures.

\footnotetext{
${ }^{20}$ Ninth Conference of Heads of State and Government of Countries Sharing French, Beirut, Oct. 18-20, 2002.

${ }^{21}$ The illiterate population was estimated at 876 million people in 2000, with a clear gap between industrialized and developing countries. We prefer to talk about illiteracy in developed countries.

${ }^{22}$ The Agency's budget for programs amounts to 110 million euros per biennium

${ }^{23}$ According to the used during the ninth Conference of the Francophonie Beirut.
} 
These Congolese requests essentially consist in asking the structures of the Francophonie to adapt to the Congo the financial, material or technical assistance necessary to solve the problems which arise in the fields of education.

Ultimately, the needs of the Congo are diverse and multiple because they are inherent in the problems posed by education in particular and the development of the country.

\section{The contribution of the International Organization of La Francophonie to education and training}

The New Technologies Organization ( Ifadem ) and others face-to-face (Initiative ÉLANAfrique) as well as the production of educational tools according to the different cultural and linguistic contexts of the countries of the African-speaking, Creole-speaking and Arabicspeaking areas. Learning a trade is based on the foundation of knowledge acquired at school and on the new technology of the International Organization of La Francophonie advocated in its objectives to help its member countries in the promotion of education and training among many others in the Congo. Education and training constitute a strategic area of intervention, both for the preservation and dissemination, both of the French language and of national languages and cultures, for the consolidation of the Francophone community by promoting understanding and understanding adhesion of the youth to the objectives of the OIF for the realization of the economic development of the Nations decided at the summit of DAKAR held of May 24-26, 1989.

The OIF supports the role devolved on CONFEMEN to contribute to the development and evaluation of educational policies within member states and governments and invite it to extend to all countries with French. And the OIF asks the competent operators of the Francophonie to put their know-how at the service of the States in order to facilitate the cooperation of our States with the international institutions which, such as the World Bank and the European Union, have been given a mandate to develop their programs in the field of education.

Thus, in line with its traditional missions and the mandates entrusted by heads of state and government, CONFEMEN has supported its member states and governments in the development and implementation of their educational policies. This has resulted in particular in the training of managers, the provision of books and textbooks, reflection and orientation documents as well as reliable and objective information on the strengths and weaknesses of their education systems and by building the capacities of various actors.

The field of reflection and analysis thus concerned covers practically all aspects related to access to education, the quality of teaching and continuing education, financing of education, vocational and technical training and teaching practices classroom and the school and out-of-school environment, school management, communication in education, in short, the management and governance of education systems.

On another level, CONFEMEN has developed, particularly since the adoption of its recovery plan in 2002, its capacities for mobilization and consultation, its expertise and its people-to-people skills with a view to an ever wider, functional and effective partnership field ${ }^{24}$.

As a framework for dialogue to promote common interest, CONFEMEN has participated in major regional and international meetings on education as well as bilateral and multilateral meetings, promoting the promotion of a functional partnership with various institutions and organizations international organizations involved in education. In addition, CONFEMEN

${ }^{24}$ Contribution of CONFEMEN the XXVI ${ }^{\text {th }}$ Ministerial Conference of the Francophonie (CMF) Montreux, Switzerland-October 2010 
has signed several agreements with partners and strengthened cooperation with them, in order, on the one hand, to increase its resources and its capacity for action for greater and better ownership of its orientations; on the other hand, to promote the point of view of the Francophonie in international forums devoted to education for all (EPT).

Likewise, the panel discussions, days of reflection and Assizes initiated by the CNFEMEN, were organized in partnership with many institutions such as the International Organization of the Francophonie (OIF), the association for the right to education in Africa '(ADEA), UNESCO, the World Bank, the International Francophone Association of School Directors (AFIDES), the African Federation of Associations of Parents of Pupils and Students (FAPE) to name a few this one.

For example, the sessions on curriculum reforms, held in Congo, in Brazzaville, from July 5 to 9, 2010, were organized in partnership with OIF, ADEA, UNESCO, Agency French Development Agency (AFD), the International Association of Francophone Mayors (AIMF) and the Islamic Development Bank (IDB). Following exchanges and fruitful discussions, a framework has been adopted by the participants in the light of the various findings on the situation of reform curricularies. This framework will be submitted to Ministers CONFEMEN during their $54^{\text {th }}$ Ministerial Session in November 2010au Senegal.

It is now firmly established that not only do these major international meetings make it possible to sensitize national actors on important issues and to maximize available resources, but also to promote the coordination of various actions between partners committed to the same cause.

CONFEMEN reiterates its commitment to continue, with ever greater dedication and selfsacrifice, the implementation of the various mandates entrusted to it by the Heads of State and Government on the occasion of their various Summits. CONFEMEN is therefore determined to do more and better, all the more so as major challenges a wait in the French speaking world. These include, among other things:

- Promote good governance in education;

- Support the establishment of effective national assessment systems with appropriate institutional foundations;

- Promote and support the use of information and communication technologies (ICT) as innovative teaching tools capable of improving the quality of teaching; and

- Strengthen the capacities for steering educational reforms;

- Work for quality education for all.

CONFEMEN is convinced that the theme of the next Summit of Heads of State and Government would find, through these different centers of interest, avenues for solutions that are at the same time realistic, relevant and sustainable, because, if we agree that education is the essential lever of sustainable development, we must also note that quality education is not limited to the acquisition of knowledge. Moreover, a number of international organizations, including the Organization for Economic Co-operation and Development (OECD), underline the urgency for our education systems to equip our learners with essential skills for the $21{ }^{\text {st }}$ century. Indeed, we believe that education must imperatively promote the development of skills that affect the different spheres of an individual's life that is to say on the social, economic, cultural and environmental level ${ }^{25}$.

Education must ultimately enable students to flourish, to exploit their full potential while promoting their integration into society and contributing to the latter's development. This is why CONFEMEN considers it essential to integrate the concept of sustainable development

${ }^{25}$ Contribution of CONFEMEN the XXVI "inisterial Conference of the Francophonie (CMF) Montreux, Switzerland-October 2010 .p.5 
into the curricula and consequently to train school personnel in the teaching and practice of such education.

The importance of getting students to develop civic skills in order to work for sustainable development; the need to introduce national languages in education in order to achieve a dual objective, namely improving learning outcomes in general and mastery of the French language in particular ; the essential partnership dynamic, both nationally and internationally, to optimize actions aimed at increasing the quality of education, are all points to which the Francophonie must attach great interest and importance.

In addition to the urgency and the importance of finding ways and means to increase the resources essential to this fight, CONFEMEN considers, in the logic of the issues underlying the themes of the Montreux Summit, that we must more than ever to act effectively in order to establish genuine and dynamic partnerships to promote the vision of sustainable development on the environmental, societal and economic levels. As such, CONFEMEN suggests the creation and strengthening of consultation and coordination mechanisms for the various actions relating to education for sustainable development. La Francophonie must also encourage the integration of the concept of sustainable development into national curricula, across all disciplines, just as it must support the training of school personnel aimed at improving the quality of education through education for sustainable development.

In continuation of the action it has undertaken at its $51^{\text {th }}$ Mauritius Ministerial session CONFEMEN calls for mastery of the French language, in interrelation with are national languages.

Language of access to information and knowledge, but also of communication, the French language cannot develop, in particular in the countries of the South; members of the Francophonie could in particular facilitate the creation of groups of experts to support cooperation programs in this area.

In the same dynamic, and in order to improve the place of French in research and populations, CONFEMEN believes that it will also be necessary to promote and strengthen the mobility of students and researchers from the South as well as their reception in Frenchspeaking establishments in the South. Higher education in the North, so as to allow the French-speaking countries of the South to develop better in this context of globalization.

These are the challenges that seem essential to us for the Francophonie. CONFEMEN, whose partnership is at the heart of the action, does not hope that the Montreux Summit will lay the groundwork for this education for sustainable development that we are calling for.

\section{CONCLUSION AND RECOMMENDATION}

The Republic of the Congo, concerned with the development of its culture and its policies, has joined the Organization International of Francophonie since 1981. Thirty-three years after the Niamey conference of February 1969, several events have passed; the initial institutions have been confirmed. A French-speaking space has emerged; ACCT has been transformed into AIF, the main operator of the International Organization of La Francophonie with several direct operators. And that determined his contribution to culture and politics in the Republic of Congo. In 1990, the Congo benefited from a pilot project of reading and cultural animation centers (CLAC) in three Departments, Bouenza, Lékoumou and Niari. Following the political events that the country experienced between 1993/1998, these centers were destroyed. 


\section{REFERENCES}

Goniced PF and Chavrin. (1981). Les relations internationales, Paris, Montchrestien.

Louis Sabourin, Gérard Conac, and Christine Dessouche Christine. (1987). The Frenchspeaking multilateral cooperation Paris, Economica , p. 26

Mapana MT. (1993). The Agency for Cultural and Technical Cooperation of the Francophonie and cooperation with the Congo, Diploma thesis from ENAM, UMNG, Congo.

Morwoha E. (1995). 25 years at the service of development and French-speaking cooperation, Paris, ACCT.

N Tenzer. (1991). Politics, What do I know ?, Paris, PUF, p.25

World Culture Report. (2000). Paris, UNESCO.

Sabourin L., Conac G., and Dessouche C. (1987). The French-speaking multilateral cooperation Paris, Economica, p. 26

Tenzer N., 1991, Politics, Que sais-je ?, Paris , PUF

www.Journal le monde of March 9, 2012

www.organizationinternationale de la francophonie.org .passeport site

www.organizationinternationale de la francophonie.org Sommet de la Francophonie, Grand-

Baie (Mauritius), October 16 and 18, 1993

www.organizationinternationale.org, genesis of the Francophonie

www.organizationinternationale.or g, report of the Secretary General of La Francophonie 2004-2006 